\title{
Histopathological helicobacter pylori verification and related regimen in the presence of esophageal strictures secondary to surgical procedures for the esophageal cancer
}

\author{
Tugrul Kesicioglu ${ }^{1}$ and Demet Sengul ${ }^{2 *}$ \\ ${ }^{1}$ Department of General Surgery, Giresun University Faculty of Medicine, 28100 Giresun, Turkey \\ ${ }^{2}$ Department of Pathology, Giresun University Faculty of Medicine, 28100 Giresun, Turkey
}

\begin{abstract}
Introduction: Esophageal strictures often occur following esophagectomy which is performed for the esophageal cancer cases. These patients require some repeated dilation procedures. The aim of this study is to investigate the effects of dietary regimens, changing because of the stenosis, on Helicobacter pylori ( $H$. pylori).

Materials and methods: In this retrospective study, 28 patients who had an operation for esophageal cancer and underwent dilation following the development of stricture. Thirty female and 30 male patients, had been admitted with the complaints of dyspepsia and did not receive treatment for the eradication of $H$. Pylori, had been randomized and included in the present study as a control group. The histopathological evaluation, hemogram, biochemistry, and endoscopic biopsy had been retrospectively analyzed.

Results: There were $26 \mathrm{H}$. pylori $(+)$ cases $(92.8 \%)$ in the stenosis group, consisting 28 patients, and 37 H. pylori $(+)$ cases $(61.6 \%)$ in the control group, consisting of 60 patients. These results were statistically significant $(p=0.003)$. The albumin level in the stenosis group was reported to be statistically low $(p=0.002)$.

Conclusion: The incidence of $H$. pylori was found to be significantly high in patients with stenosis. It was ascribed this outcome to changes in dietary regimens and our findings showed that the dietary regimens of all the cases, had underwent esophagectomy, should be regulated during the postoperative period considering $H$. pylori. A significant relationship between $H$. pylori and stenosis was detected.
\end{abstract}

\section{Introduction}

Helicobacter pylori (H. pylori) is a spiral-shaped, gram-negative bacteria colonized in the gastric mucosa [1]. The infection rate of the global population by $H$. pylori has been reported as being more than 50\% [2]. The infection with $H$. pylori occurs during the early stages of the life and can last forever if untreated [3]. Although the majority of individuals remain asymptomatic, some infected cases, however, develop gastritis. On the other hand, untreated individuals may develop atrophic gastritis and gastric adenocarcinoma following metaplasia. H. pylori infection-induced gastritis begins with an acute phase, accompanied by lamina propria and gastric epithelial infiltration of polymorphonuclear leukocytes (PMNs) [4]. After the acute phase, the $H$. pylori infection-induced gastritis progresses to chronic gastritis, characterized by the accumulation of lymphocytes or plasma cells, the formation of lymphoid follicles, and the hyperplasia of cells containing gastric glands [5].

Dietary habits change in association with the severity of stenosis in patients, develop esophageal stenosis, and there is a change from solid, fluid, and pureed foods. In the present study, we intended to discuss the effects of this changing nutritional model on $H$. pylori.

\section{Materials and methods}

\section{Criteria for incorporation into the study}

A retrospective analysis by enrolling the documents of the cases with the operation for esophageal cancer and bougie dilation, following the development of esaphageal stricture between 2011 and 2017 were incorporated in the study. Twenty-eight patients Thirty female and 30 male patients who were admitted to the the clinic with gastric complaints and had not received any treatment for the eradication of $H$. pylori were randomized and the data were retrospectively evaluated.

\section{Histopathological and laboratory evaluation}

The complete blood count, white blood cells, hematocrit, platelet, neutrophil levels, and the upper and lower levels of albumin, creatinine, and glucose values of the patients were obtained. The presence of H. pylori was revealed histopathologically (Figure 1). Patients with incomplete results were excluded from the study.

\section{Statistical analysis}

The statistical analysis were performed by using SPSS 13.0 computer program. The descriptive statistics for the continuous variables were

*Correspondence to: Demet Sengul, MD, Assistant Professor of Pathology, The Founder Chairman, Pathology, The Founder Chairman, Education Laboratories, Giresun University Faculty of Medicine, Nizamiye Compound, Mumcular Avenue, TR28100 Giresun, Turkey, Tel: 904543101600; Fax: 904543101699; E-mail: dr.demetkilci@mynet.com; demet.sengul@giresun.edu.tr

Key words: Esophageal stenosis, Helicobacter pylori, esophageal cancer

Received: September 12, 2018; Accepted: September 25, 2018; Published: September 28, 2018 


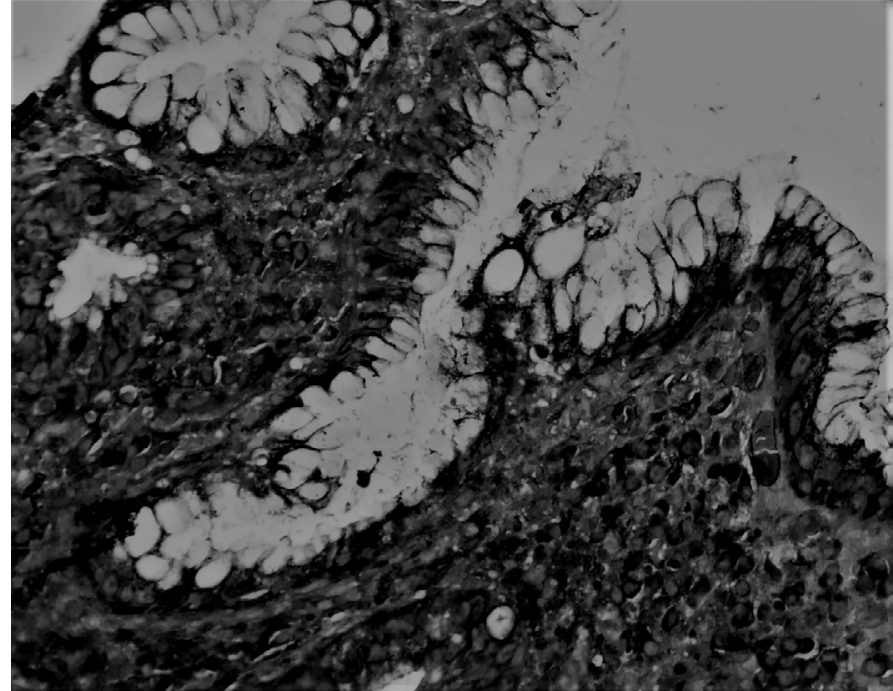

Figure 1. A photomicropragh revealing H. pylori positivity, 3+ (Giemsa, Original magnification, $40 \mathrm{x} 0.10$ )

presented as mean, standard deviation, maximum and minimum values while count and percentages for categorical variables. One-way ANOVA was used to compare group means. Duncan multiple comparison test was also used to determine different group means followed by ANOVA. Pearson correlation analysis was performed to determinate the linear relationships among the variables, In addition, chi-square test was performed to display the association between categorical variables and $p$ value less than 0.05 was considered as statistically significant.

\section{Results}

Of the 28 patients with stenosis included in the study, 19 were females, and nine were males (age range 23-86, median: 56.3), whereas in the non-stenosis control group 30 females and 30 males, (age range: 20-78, median: 52.5) were identified. In the stenosis group, H. pylori was absent in two of the 28 patients irrespective of gender (one male and one female), whereas $H$. pylori was detected in 26 patients. No $H$. pylori was detected in 23 ( 12 males and 11 females) of the 60 patients in the control group but was detected in 37 of the patients ( 18 females and 19 males). These results were found to be statistically significant $(p=0.003)$ (Table 1). Comparison of the stenosis group with the control group demonstrated that the statistical significance was found only the albumin level with regards to biochemistry parameters $(p=0.002) . H$. pylori positivity rate in stenosis group was $92.8 \%$ while $61.6 \%$ in control group.

\section{Discussion}

Epidemiological studies show that $H$. pylori is one of the most prevalent bacterial infections worldwide [6-8]. The infection rate of the global population by $H$. pylori was reported as being more than $50 \%$. This rate could rise up to approximately $80-90 \%$ in developing countries [2,9]. The incidence of $H$. pylori was found to be $56.5 \%$ in a previous study in the eastern of Turkey [10]. Infection with $H$. pylori occurs during the early stages of life and can last forever if untreated [3]. H. pylori infection is transmitted from one individual to another, and a low hygienic level plays a vital role in its spread [11].

Most individuals infected with $H$. pylori present with subclinical gastritis. However, a small proportion of infected patients progress to a clinical disease state mostly brought about by gastritis. In some cases, the infection and colonization result in more severe disease symptoms. $H$. pylori is the etiologic agent of peptic ulcer; $75 \%$ of gastric ulcers and $90 \%$ of duodenal ulcers are associated to $H$. pylori infection [12], as well as two different types of gastric cancers: adenocarcinoma and mucosaassociated lymphoid tissue (MALT) lymphoma [13]. As a result of this correlation, $H$. pylori is the only class of bacteria classified as class I carcinogen by the World Health Organization [14]. Gastric cancer is still the second most common cause of cancer mortality worldwide, and this high rate may reflect the incidence of $H$. pylori infection [15].

Due to the association of $H$. pylori with various severe gastric diseases, some studies have been conducted to throw light on bacterial, host, and environmental factors affecting disease progression. Virulence factors of bacteria were clarified in these studies, and attempts to reveal the relationship of feeding habits with $H$. pylori infection were made. Studies investigating the relationship of diet with $H$. pylori showed that $H$. pylori is less prevalent in populations fed mainly on fruitsvegetables and vitamin $C$ [16]. In another study, some types of raw fast food types, such as fruit salads, indicated that they might be sources of H. Pylori resistant and virulent strains [17]. H. pylori was found to be higher in populations fed on carbohydrate-rich foods, processed meat, refined grains and food containing saturated fat [18]. The high salt concentration in the stomach could destroy the mucosal barrier of the stomach, thereby facilitating the colonization of $H$. pylori and causing inflammation and gastritis. Processed meat contributes to the pathogenicity of $H$. pylori due to their high salt content [19]. Zhang et al. reported that acute and chronic alcoholic consumption, such as

Table 1. The descriptive statistics of the cases

\begin{tabular}{|c|c|c|c|c|c|c|}
\hline & $\mathbf{n}$ & Mean & SD & Min & Max & $p$-value \\
\hline \multirow[t]{3}{*}{ Age } & 60 & 52.5 & 11,514 & 32 & 92 & \multirow[t]{2}{*}{,339 } \\
\hline & 28 & 56.3 & 15,939 & 23 & 87 & \\
\hline & 88 & 54,7 & 13,084 & 23 & 92 & \\
\hline \multirow[t]{3}{*}{$\mathrm{Hb}$} & 60 & 12,50 & 2,025 & 8 & 17 & \multirow[t]{2}{*}{, 371} \\
\hline & 28 & 12,11 & 1,876 & 9 & 17 & \\
\hline & 88 & 12,38 & 1,976 & 8 & 17 & \\
\hline \multirow[t]{3}{*}{ Hct } & 60 & 37,20 & 5,616 & 24 & 49 & \multirow[t]{2}{*}{, 427} \\
\hline & 28 & 36,21 & 5,502 & 28 & 49 & \\
\hline & 88 & 36,88 & 5,569 & 24 & 49 & \\
\hline \multirow[t]{3}{*}{ WBC } & 60 & 7,598 & 3,8817 & 1,8 & 25,0 & \multirow[t]{2}{*}{,023 } \\
\hline & 28 & 5,803 & 2,4689 & 2,0 & 11,0 & \\
\hline & 88 & 7,019 & 3,5760 & 1,8 & 25,0 & \\
\hline \multirow[t]{3}{*}{ Plt } & 60 & 270,65 & 123,839 & 67 & 702 & \multirow{2}{*}{, 150} \\
\hline & 28 & 6166,87 & 32454,225 & 79 & 178000 & \\
\hline & 88 & 2172,66 & 18430,981 & 67 & 178000 & \\
\hline \multirow[t]{3}{*}{ ALT } & 60 & 18,94 & 17,766 & 6 & 142 & \multirow[t]{2}{*}{,284 } \\
\hline & 28 & 15,27 & 8,026 & 6 & 39 & \\
\hline & 88 & 17,75 & 15,362 & 6 & 142 & \\
\hline \multirow[t]{3}{*}{ AST } & 60 & 33,02 & 48,837 & 2 & 341 & \multirow[t]{2}{*}{,089 } \\
\hline & 28 & 17,57 & 6,976 & 9 & 38 & \\
\hline & 88 & 27,98 & 40,833 & 2 & 341 & \\
\hline \multirow[t]{3}{*}{ Albumin } & 60 & 3.9 & ,876 & 2 & 5 & \multirow[t]{2}{*}{,003 } \\
\hline & 28 & 3,1 & ,447 & 2 & 5 & \\
\hline & 88 & 3,5 & ,711 & 2 & 5 & \\
\hline \multirow[t]{3}{*}{ Globulin } & 60 & 3,2 &, 533 & 2 & 4 & \multirow[t]{2}{*}{, 040} \\
\hline & 28 & 2,8 & ,772 & 1 & 4 & \\
\hline & 88 & 3 & 625 & 1 & 4 & \\
\hline \multirow[t]{3}{*}{ Calcium } & 60 & 8,92 & 1,362 & 1 & 13 & \multirow[t]{2}{*}{, 370} \\
\hline & 20 & 9,17 & ,639 & 8 & 11 & \\
\hline & 88 & 9,00 & 1,181 & 1 & 13 & \\
\hline
\end{tabular}

SD: Standard deviation; WBC: White blood cell; Hb: Hemoglobin; Hct: Hemotocrit; PIt: Platelet 
Kesıcıoglu T (2018) Histopathological helicobacter pylori verification and related regimen in the presence of esophageal strictures secondary to surgical procedures for the esophageal cancer

salt causes disruption of the gastric mucosal barrier, and increased mucosal permeability, chemical inflammation, and density of $H$. pylori colonization [20]. In another study, Hosoda $\mathrm{K}$ et al. suggested that vitamin $\mathrm{D}_{3}$ had antibacterial effects against $H$. pylori, but that it was ineffective against other bacteria. Treatment with vitamin $\mathrm{D}_{3}$ was shown to result in the collapse of $H$. pylori cell membrane and the eventual destruction of bacteria cells [21]. Chili, capsaicin, Garlic/ Allium, Curcumin, Cumin, Turmeric, Nutmeg, and Cardamom spices, which are frequently used in the kitchen, were shown to reduce $H$. pylori colonization through their anti-inflammatory effects and to demonstrate anti-helicobacter effects [22-25]. All these studies in light of data suggest that there is a close relationship between nutritional patterns and $H$. pylori.

Esophageal stenosis is a common complication especially observed following esophagectomy, with the resultant complication of a patient's life. Postoperative stenosis was shown to develop in more than $40 \%$ of patients who underwent esophagectomy [7]. Our clinical experience showed that the stenosis could cause malnutrition by limiting a patient's oral intake. The patients had a difficulty consuming solid food due to the stenosis, which is why they tended to deviate to liquid food. In the present study, patients who had underwent the dilation and subjected to endoscopic biopsy following postoperative stenosis were compared with healthy subjects. The level of albumin was detected to be significantly low in the stenosis group $(p=0.002)$. These results showed the stenosisrelated chronic malnutrition being developed in the stenosis group.

Comparison of the stenosis group with the control group in respect of the presence of $H$. pylori demonstrated that the level of $H$. pylori in the stenosis group was significantly higher $(p=0.003)$. We suggest that the increased level of $H$. pylori in the oral intake restricted stenosis group was due to the varied nutritional regimens and weakening immune system unlike observed with the normal population. In the stenosis group, since the solid foods can not be swallowed, the intake of vegetables, fruits and vitamins decreases and more liquid foods rich in calories are instead consumed. Various studies showed that $H$. pylori is high in dietary regimens poor in antioxidant vitamins and vegetable oils [26-29]. This may account for the high rate of $H$. pylori in the stenosis group.

\section{Conclusion}

In conclusion, the increased incidence of $H$. pylori in patients with stenosis is associated with the changing dietary regimen. We recommend that all the patients who had underwent esophagectomy should regulate their dietary regimens during the postoperative period through considering H. pylori.

\section{Conflict of interest}

No conflict of interest relevant to this article has been declared.

\section{Acknowledgements}

It has not been used any funding for the present work. TK and DS had contributed in constituting the notion and hypothesis, intellectual planning and management of the study, writing the whole manuscript, its linguistic and academical revisions. Besides, DS had contributed in collecting the data, performing the statistical analysis. All the authors finally approved the submitted and proof versions without any conflict of interest.

We would like to thank all the staff and personnel of Department of Gastroenterology, General Surgery, and Pathology.

\section{References}

1. Marshall BJ, Warren JR (1984) Unidentified curved bacilli in the stomach of patients with gastritis and peptic ulceration. Lancet 1: 1311-1315. [Crossref]

2. The EUROGAST Study Group (1993) Epidemiology of, and risk factors for Helicobacter pyloriinfection among 3194 asymptomatic subjects in 17 populations. Gut 34: 1672-1676. [Crossref]

3. Kuipers EJ, Israel DA, Kusters JG, Gerrits MM, Weel J, et al. (2000) Quasispecies development of Helicobacter pylori observed in paired isolates obtained years apart from the same host. J Infect Dis 181: 273-282. [Crossref]

4. Chen XY, Liu WZ, Shi Y, Zhang DZ, Xiao SD, et al. (2002) Helicobacter pylori associated gastric diseases and lymphoid tissue hyperplasia in gastric antral mucosa. $J$ Clin Pathol 55: 133-137. [Crossref]

5. White JR, Winter JA, Robinson K (2015) Differential inflammatory response to Helicobacter pylori infection: etiology and clinical outcomes. J Inflamm Res 8: 137147. [Crossref]

6. Zhong S, Wu Q, Sun S, Gu B, Zhao M, et al. (2014) Risk factors of benign anastomostic strictures after esophagectomy with cervical reconstruction. Zhonghua Wei Chang Wai Ke Za Zhi 17: 877-880. [Crossref]

7. van Heijl M, Gooszen JA, Fockens P, Busch OR, van Lanschot JJ, et al. (2010) Risk factors for development of benign cervical strictures after esophagectomy. Ann Surg 251: 1064-1069. [Crossref]

8. Malfertheiner P, Megraud F, O'Morain CA, Gisbert JP, Kuipers EJ, et al. (2017) Management of Helicobacter pylori infection-the Maastricht V/Florence Consensus Report. Gut 66: 6-30. [Crossref]

9. Salih BA (2009) Helicobacter pylori Infection in Developing Countries: The Burden for How Long? Saudi J Gastroenterol 15: 201-207. [Crossref]

10. Suvak B, Dulger AC, Suvak O, Aytemiz E, Kemik O (2015) The prevalence of helicobacter pylori among dyspeptic patients in an earthquake-stricken area. Clinics (Sao Paulo) 70: 69-72. [Crossref]

11. Manfredi M, Iuliano S, Gismondi P, Bizzarri B, Gaiani F, et al. (2016) Helicobacter Pylori Infection: We Should Always Verify the Intrafamilial Transmission. Biol Med (Aligarh) 9: 366.

12. Ernst PB, Gold BD (2000) The disease spectrum of Helicobacter pylori: the immuno pathogenesis of gastroduodenal ulcer and gastric cancer. Annu Rev Microbiol 54: 615640. [Crossref]

13. Venerito M, Vasapolli R, Rokkas T, Delchier JC, Malfertheiner P (2017) Helicobacter pylori, gastric cancer and other gastrointestinal malignancies. Helicobacter 22: e12413. [Crossref]

14. No authors listed (1994) Infection with Helicobacter pylori. IARC Monogr Eval Carcinog Risks Hum 61: 177-240. [Crossref]

15. Crew KD, Neugut AI (2006) Epidemiology of gastric cancer. World J Gastroenterol 12 354-362. [Crossref]

16. Aditi A, Graham DY (2012) Vitamin C, gastritis, and gastric disease: a historical review and update. Dig Dis Sci 57: 2504-2515. [Crossref]

17. Hemmatinezhad B, Momtaz H, Rahimi E (2016) VacA, cagA, iceA and oipA genotypes status and antimicrobial resistance properties of Helicobacter pylori isolated from various types of ready to eat foods. Ann Clin Microbiol Antimicrob 15: 2. [Crossref]

18. Mard SA, Khadem Haghighian H, Sebghatulahi V, Ahmadi B (2014) Dietary Factors in Relation to Helicobacter pylori Infection. Gastroenterol Res Pract 2014: 826910.

19. Caruso ML, Fucci L (1990) Histological identification of Helicobacter pylori in early and advanced gastric cancer. J Clin Gastroenterol 12: 601-602.

20. Zhang L, Eslick GD, Xia HH, Wu C, Phung N, et al. (2010) Relationship between alcohol consumption and active Helicobacter pylori infection. Alcohol Alcohol 45: 8994. [Crossref]

21. Hosoda K, Shimomura H, Wanibuchi K, Masui H, Amgalanbaatar A, et al. (2015) Identification and characterization of a vitamin D3 decomposition product bactericidal against Helicobacter pylori. Sci Rep 5: 8860. [Crossref]

22. Mahady GB, Pendland SL, Yun G, Lu ZZ (2002) Turmeric (Curcuma longa) and curcumin inhibit the growth of Helicobacter pylori, a group 1 carcinogen. Anticancer Res 22: 4179-4181. [Crossref]

23. Holzer P, Pabst MA, Lippe IT (1989) Intragastric capsaicin protects against aspirin induced lesion formation and bleeding in the rat gastric mucosa. Gastroenterology 96 : 1425-1433. [Crossref] 
Kesıcıoglu T (2018) Histopathological helicobacter pylori verification and related regimen in the presence of esophageal strictures secondary to surgical procedures for the esophageal cancer

24. Cellini L, Di Campli E, Masulli M, Di Bartolomeo S, Allocati N (1996) Inhibition of Helicobacter pylori by garlic extract (Allium sativum). FEMS Immunol Med Microbiol 13: 273-277. [Crossref]

25. De R, Kundu P, Swarnakar S, Ramamurthy T, Chowdhury A, et al. (2009) Antimicrobial activity of curcumin against Helicobacter pylori isolates from India and during infections in mice. Antimicrob Agents Chemother 53: 1592-1597. [Crossref]

26. Kim HJ, Kim MK, Chang WK, Choi HS, Choi BY, et al. (2005) Effect of nutrient intake and Helicobacter pylori infection on gastric cancer in Korea: a case-control study. Nutr Cancer 52: 138-146. [Crossref]
27. Sezikli M, Güzelbulut F, Akkan Çetinkaya Z (2016) Influence of vitamin C and $E$ supplementation on the eradication rates of triple and quadruple eradication regimens in Helicobacter pylori infection. Turk J Gastroenterol 27: 290-291.

28. Ikezaki H, Furusyo N, Jacques PF, Shimizu M, Murata M, et al. (2017) Higher dietary cholesterol and $\omega-3$ fatty acid intakes are associated with a lower success rate of Helicobacter pylori eradication therapy in Japan. Am J Clin Nutr 106: 581-588. [Crossref]

29. Castro M, Romero C, de Castro A, Vargas J, Medina E, et al. (2012) Assessment of Helicobacter pylori eradication by virgin olive oil. Helicobacter 17: 305-311. [Crossref]

Copyright: $\odot 2018$ Kesicioglu T. This is an open-access article distributed under the terms of the Creative Commons Attribution License, which permits unrestricted use, distribution, and reproduction in any medium, provided the original author and source are credited. 